Girişimsel Kardiyologlar Arasında Atriyal Fibrilasyon Farkındalık Anketi Değerlendirmesi

\title{
A Survey Among Invasive Cardiologists to Assess Their Awareness of Atrial Fibrillation
}

\author{
${ }^{1}$ Kafkas Üniversitesi Tıp Fakültesi, Kardiyoloji Ana Bilim Dalı, Kars, Türkiye \\ ${ }^{2}$ Diyarbakir Gazi Yasargil Eğitim ve Araştırma hastanesi, Kardiyoloji, Diyarbakır, Türkiye \\ ${ }^{3}$ Cizre Devlet Hastanesi, Kardiyoloji, Şırnak, Türkiye \\ ${ }^{4}$ Bingöl Devlet Hastanesi, Kardiyoloji, Bingöl, Türkiye \\ ${ }^{5}$ Ankara Üniversitesi Tıp Fakültesi, Biyoistatistik Ana Bilim Dalı, Ankara, Türkiye
}

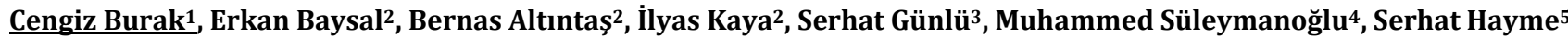

\section{$\ddot{O} Z$}

GíRIŞ ve AMAÇ: Atriyal fibrilasyon (AF), farklı klinik durumlarda ortaya çıkabilir ve çeşitli tedavi seçeneklerine sahiptir. Bu nedenle, gerçek yaşam koşullarında klinik uygulama da heterojen olabilir. Bu araştırmanın temel amact, invazif kardiyologların $A F^{\prime}$ ye yaklaşımını ve bu konudaki tedavi yaklaşımlarını değerlendirmektir.

YÖNTEM ve GEREÇLER: 2017 Girişimsel kardiyoloji kongresinde, katılımcıların rastgele seçildiği ancak katılımın gönüllük esasına dayandiğı bir anket çalışması yapılmış ve 134 anket sonucu değerlendirilmiştir. Anket formu, i) AF'yi tanıma ve belirli durumlarda medikal tedavi yaklaşımları, ii) $A F$ ablasyonu yaklaşımları ve iii) stent takılan hastalarda antikoagülasyon ve antiplatelet tedavinin yönetimi konularını içermiştir.

BULGULAR: AF ve hafif mitral darlı̆ğ olan hastada, katılımcıların çoğu yeni oral antikoagülan kullanımını tercih ederken, katılımclların dörtte biri vitamin $K$ antagonisti kullanmayı tercih etmiştir. CHA2DS2-VASc skoru 0, hipertrofik kardiyomiyopatisi olan AF hastasinda katılımcıların çoğu asetilsalisilik asit kullanmayı tercih etmiş, oral antikoagülan tercih oranı ise \%33.58 olmuştur. Semptomatik AF hastalarında hekimlerin \%73,88' $i$ üçüncü ataktan sonra ablasyonu tercih etmiş. Akut miyokard enfarktüsü nedeniyle ilaç kapl stent takılan hastalarda ikili antiplatelet tedavi ile beraber oral antikoagülasyon süresine bakıldiğında, çoğunlukla 3 ay üçlü tedavi, 12 aya kadar ikili tedavi seçeneği tercih edilmiştir (\%64.18).

TARTIŞMA ve SONUÇ: Mevcut araştırma, girişimsel kardiyologlar arasinda atriyal fibrilasyona yaklaşım konusunda farklılıklar ve bazı durumlarda kılavuzlarla uyumsuz yaklaşımlar olduğunu göstermiştir. Bu sonuç, kllavuzların yetersiz takibinden veya bazı konularda yeterli veri ile desteklenen net bir tavsiyenin bulunmayışından kaynaklı olabilir.

Anahtar Kelimeler: Atriyal fibrilasyon, anket çalısması, oral antikoagülan tedavi, ablasyon

\section{ABSTRACT}

INTRODUCTION: Atrial fibrillation $(A F)$ may occur in different clinical situations and has various treatment options. Therefore, clinical practice in real-life conditions may also be heterogeneous. The main aim of this survey was to evaluate the treatment approaches taken by invasive cardiologists in response to $A F$.

METHODS: At the 2017 interventional cardiology congress, a survey was conducted in which voluntary participants were randomly assigned, and 134 survey results were evaluated. The survey questionnaire covered topics of $i$ ) $A F$ recognition and medical treatment approaches in certain situations, ii) approaches to AF ablation, and iii) the management of anticoagulation and antiplatelet therapy in patients with recent stent implantations.

RESULTS: Most participants preferred novel oral anticoagulation in patients with $A F$ and mild mitral stenosis, but one-quarter of the participants preferred using VKA. For $A F$ patients with hypertrophic cardiomyopathy whose CHA2DS2-VASc score was zero, $58.96 \%$ of participants preferred acetylsalicylic acid. Regarding their approach to ablation, $73.88 \%$ of physicians preferred ablation after third attack in symptomatic AF patients. When it came to the duration of prescribing oral anticoagulants in combination with dual antiplatelet therapy for patients with implanted drugeluting stents due to acute myocardial infarctions, $64.18 \%$ of physicians preferred to prescribe triple therapy for three months, followed by 12 months of dual therapy.

DISCUSSION and CONCLUSION: The present survey showed differences in the approach to AF and, in some cases, incompatibility with the guidelines. This may be due to insufficient follow-up of the guidelines, or it may be due to a lack of clear recommendations supported by sufficient data on some subjects.

Keywords: Atrial fibrillation, survey study, oral anticoagulant therapy, ablation

İletişim / Correspondence:

Dr. Cengiz Burak

Kafkas Üniversitesi Tip Fakültesi, Kardiyoloji Ana Bilim Dalı, Kars, Türkiye

E-mail: cengizburaktyih@yahoo.com.tr

Başvuru Tarihi: 25.11.2018

Kabul Tarihi: 09.05.2019 


\section{INTRODUCTION}

Atrial fibrillation $(\mathrm{AF})$ is the most common type of sustained arrhythmia, and its prevalence in worldwide is approximately $3 \%$ in adults aged 20 years or older $(1,2)$. In Turkey, it is estimated that the incidence of chronic AF is $1 / 35.000$ adults per year and its prevalence is $1 / 310.000$ adults (3). Due to the symptoms and related thromboembolic complications, AF can lead to several adverse outcomes ranging from the deterioration in quality of life to death. For that reason, the current guidelines in the management of AF patients are constantly being updated in the light of new information. Given that $\mathrm{AF}$ can manifest in a variety of clinical situations and different treatment options are available, physician responses to these situations may not be equally homogeneous. It is not known exactly how well the current guidelines can be adopted for physicians in clinical practice. To partly clarify this issue, we share the results of an AF awareness questionnaire that was conducted at the 2017 interventional cardiology congress.

\section{MATERIALS and METHODS}

We conducted a paper-based survey of cardiologists attending the 2017 interventional cardiology congress. Cardiologists participating in the study were required to be experts and fellowships were not accepted. The questionnaire was randomly offered to the participants, but the participation in the survey was voluntary. The demographic data related with age, sex and years of professional experience were collected. Participants were queried on; i) AF recognition and medical treatment approaches in a certain situation, ii) approaches to AF ablation, and iii) the perioperative management of anticoagulation and antiplatelet therapy in patients with recent stent implantations. To identify the bleeding risk, HAS-
BLED (Hypertension, Abnormal renal/liver function, Stroke, Bleeding history or predisposition, Labile international normalized ratio, Elderly $(>65$ years), Drugs/alcohol concomitantly) score was used in some circumstances (4). The CHA2DS2-VASc score (congestive heart failure, hypertension, age, diabetes mellitus, stroke, vascular disease, and sex) was used to define the stroke risk (5). An approval was received for the evaluation and publication of the survey results, but the ethics committee approval was not required because no private patient data was shared. We performed all statistical analyses using SPSS version 21 (IBM Corporation) and descriptive statistics as appropriate.

\section{RESULTS}

The average age of participants (115 males and 19 females) was $39.3 \pm 5.6$ years. The duration of experience of participants was $13.5 \pm 5.2$ years in general cardiology practices and $8.0 \pm 4.3$ years in invasive cardiology practices.

While $57.46 \%$ of participants defined a minimum duration of 30 seconds for an AF episode, the majority of the remainder stated that this time as a minimum of 10 seconds. Three-quarters of the participants preferred direct oral anticoagulants (DOACs), while the remainder preferred vitamin $\mathrm{K}$ antagonist (VKA) in patients with mild mitral stenosis. While $84.18 \%$ of physicians preferred using the rhythm control strategy in the same patient, only $14.23 \%$ of physicians preferred using the rate control strategy. For AF patients with hypertrophic cardiomyopathy whose CHA2DS2-VASc score was zero, $58.96 \%$ of physicians preferred to prescribe acetylsalicylic acid (ASA), while $33.58 \%$ of physicians preferred to prescribe oral anticoagulants (OACs) (Figure 1). 


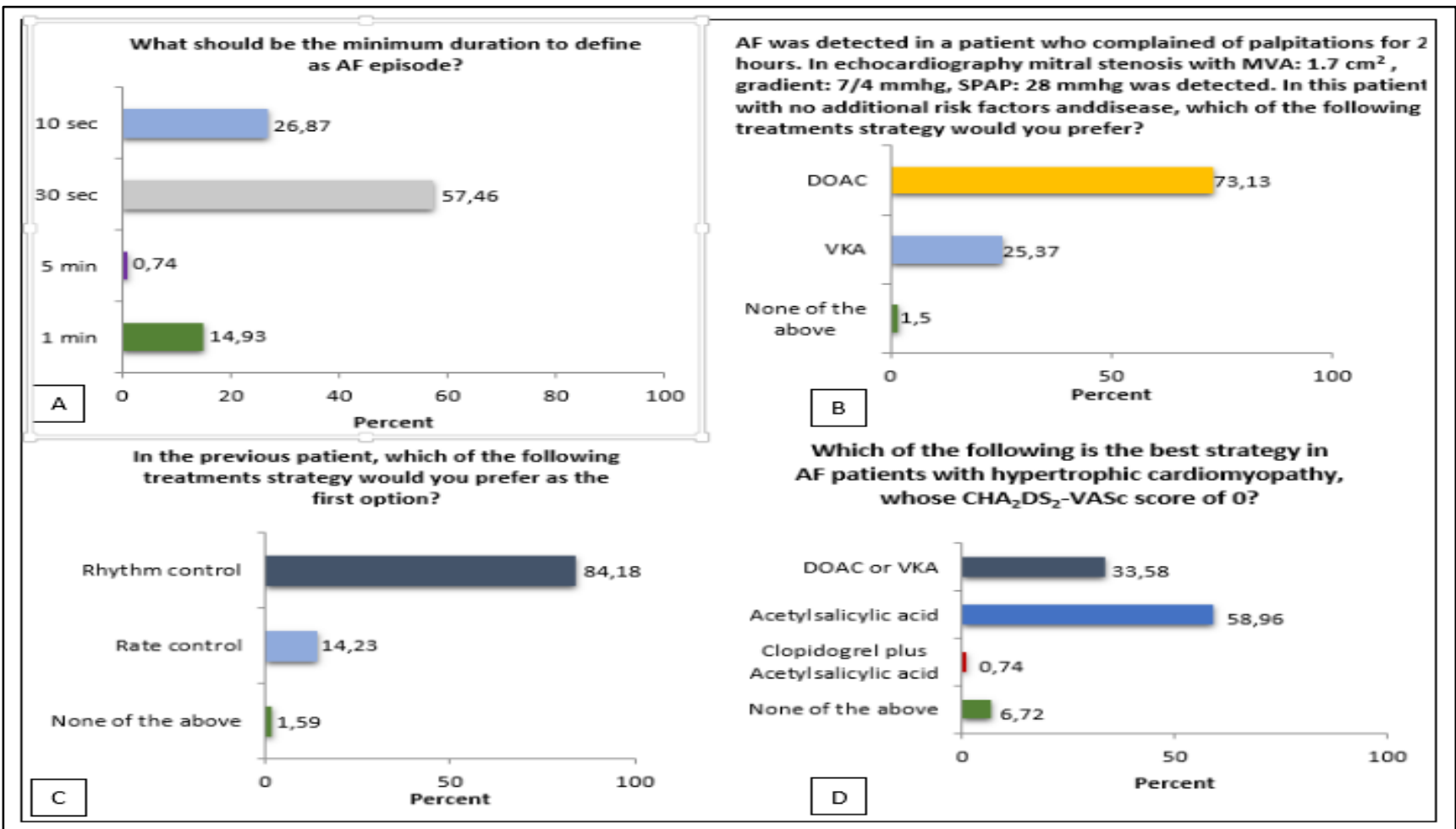

Figure 1. AF recognition and medical treatment approaches in certain situations. AF; Atrial fibrillation, MVA; Mitral valve area, SPAB; systolic pulmonary artery pressure, DOACs; Direct oral anticoagulants, VKA; Vitamin K antagonist

When considering the ablation option for paroxysmal AF patients without structural heart disease, $73.88 \%$ of physicians preferred ablation after the third attack in symptomatic patients, and that preference rate decreased to $48.51 \%$ in asymptomatic patients (Figure 2).

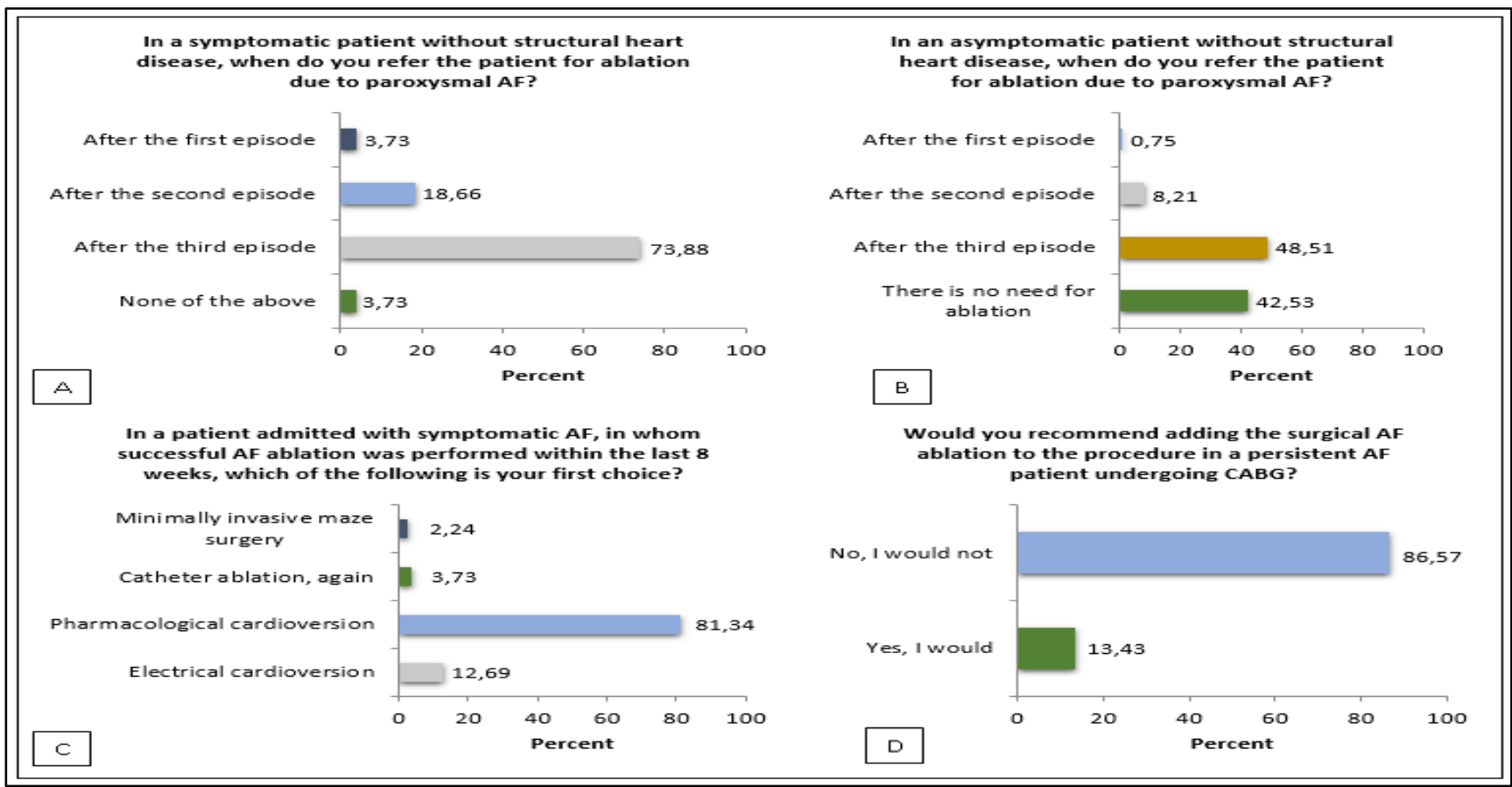

Figure 2. Approaches to atrial fibrillation in terms of ablation and surgery. AF; Atrial fibrillation, CABG; Coronary artery bypass grafting 
In patients admitted with symptomatic $\mathrm{AF}$ and in whom successful AF ablation was performed within the previous eight weeks, $81.34 \%$ of physicians preferred pharmacological cardioversion. Most survey participants did not recommend adding surgical AF ablation to the procedure in patients with persistent AF undergoing coronary artery bypass grafting (CABG).

In non-valvular AF patients with high bleeding risk, bare-metal stents (BMSs) were preferred over drug-eluting stents (DESs) in cases of acute myocardial infarction. The preference for the use of BMSs was more prominent in cardiologists with more than 13 years of experience $(\mathrm{p}=0.01)$. When considering the use of OACs together with dual antiplatelet therapy (DAPT) in patients who had had stent implantations due to acute myocardial infarctions, $64.18 \%$ of physicians preferred using DOACs in AF patients with HAS-BLED scores of 2 and CHA2DS2-VASc scores of 1 for men or 2 for women, respectively.

Regarding the duration of prescribing OACs in combination with DAPT in patients with implanted DESs due to acute myocardial infarction, $64.18 \%$ of physicians prescribed the triple therapy for three months, followed by dual therapy for 12 months. However, one-quarter of participants chose to prescribe the triple therapy for one month, followed by dual therapy for 12 months in these cases. In cases of elective percutaneous coronary intervention, the preferred triple therapy prescription times were shortened to one month by $41.79 \%$ of participants (Figure 3).

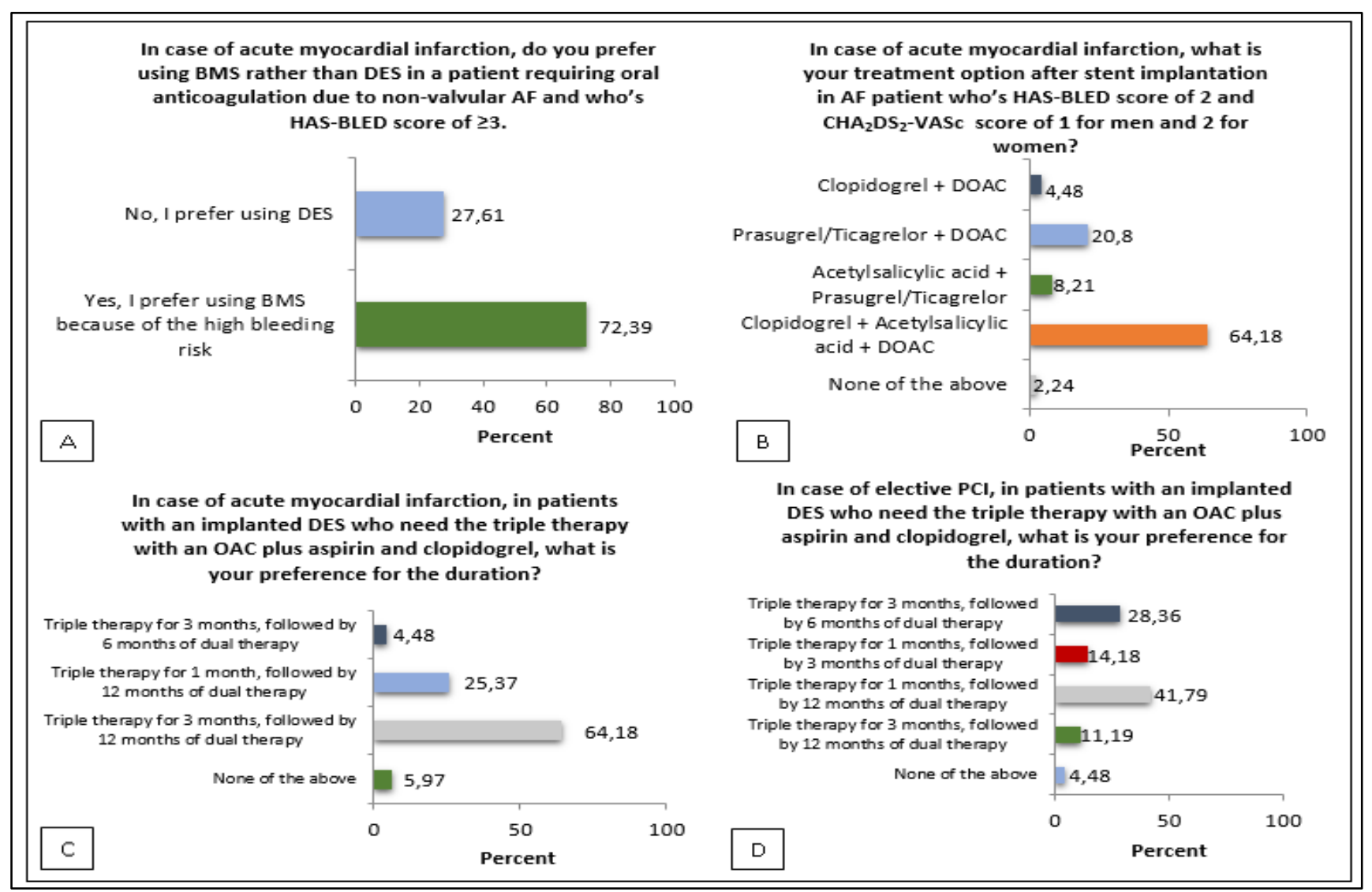

Figure 3. The management of anticoagulation and antiplatelet therapy in patients with recent stent implantation. BMS; Bare-metal stent, DES; Drug-eluting stent, DOACs; Direct oral anticoagulants, OAC; Oral anticoagulant, PCl; Percutaneous coronary intervention 


\section{DISCUSSION}

With this survey, we had an opportunity to gather information about the different approaches among Turkish cardiologists to AF in different clinical situations. This questionnaire reveals that the approach of experienced invasive cardiologists to $\mathrm{AF}$ is heterogeneous. The survey was conducted at the congress instead of the single center, so that we could ensure that opinions were homogeneously distributed across the country and thus support the overall or partial generalizability of the results.

As defined in the 2016 European Society of Cardiology (ESC) guidelines for the management of $\mathrm{AF}$, the duration of 30 seconds or more is required to be diagnosed with AF (6). An accurate expression of this period in our survey seems to be low. Considering that it has been almost two years since the publication of these 2016 guidelines, the followon by invasive cardiologists may appear to be inadequate. In cases where AF accompanies valvular heart disease, the thromboembolic risk and the possible risk of stroke increases (7). Most participants preferred using DOACs in patients with mild mitral stenosis and AF, which is consistent with the current guidelines. It is important to state that, in patients with moderate to severe mitral stenosis and AF, VKA should be preferred over DOACs (6).

It is not uncommon for patients with hypertrophic cardiomyopathy to also have AF. ASA is not proposed for these patients, and it is recommended that DOACs or VKA must be prescribed regardless of the CHA2DS2-VASc scores. Although not compatible with the guidelines, it should be noted that more than half of our participants preferred to use ASA in these cases. This result may suggest that invasive cardiologists do not have enough experience in the treatment approach for this situation.

Catheter ablation is recommended for patients with symptomatic paroxysmal $\mathrm{AF}$ after the failure of antiarrhythmic drug therapy $(8,9)$. Therefore, AF ablation is becoming increasingly frequent in Turkey, in parallel to the world. According to the survey results, the participants did not recommend
AF ablation after the first episode, even in symptomatic patients. This implies that the participants may be reluctant to perform an invasive intervention. Also, this may be due to insufficient experience for $\mathrm{AF}$ ablation or that physicians prefer to continue following conventional trends in the planning of AF therapy. Although several clinical trials have shown that catheter ablation improves exercise capacity and the quality of life, there is no conclusive data for catheter ablation in asymptomatic patients (10). Consistent with this data, most participants preferred not to use catheter ablation because of the lack of evidence that catheter ablation is effective for asymptomatic patients.

Recent guidelines recommend to add surgical ablation to $\mathrm{CABG}$ for symptomatic patients with $\mathrm{AF}$ that is refractory or intolerant to antiarrhythmic drug (AAD) (class I recommendation), and also who have not been treated with AAD before (class IIa recommendation) (8). However, the overwhelming majority of invasive cardiologists who participated in our survey do not suggest adding surgical ablation to CABG. This may be because concomitant AF is not cared for enough in patients referred for surgery or because the clinical consequences are ignored.

The superiority of newer-generation DESs over BMSs in high bleeding risk patients has been demonstrated by two randomized trials $(11,12)$. In the 2014 European Society of Cardiology/European Association for Cardio-Thoracic Surgery guidelines on myocardial revascularization, the use of DESs were recommended in patients with low bleeding risks, but this recommendation was unclear for patients with high bleeding risks. This approach was consistent with participant preferences (13). However, in the DAPT guideline published after our questionnaire, the new generation DES proposal with regard to bleeding risk was more clearly expressed, and we expect that the diversity reflected in our survey results will be eliminated (14).

Even if there was a gap of evidence for using DAPT in AF patients for a long time, the number of prasugrel or ticagrelor prescriptions together with DOACs preferences of participants is incompatible with the guidelines. According to four DOACs AF trials, it is likely that the efficacy of DOACs over VKA is maintained in patients exposed to antiplatelet therapy due to AF (15-18). The triple 
treatment option should be preferred for one or six months considering the risk of ischemia and bleeding in patients with anticoagulation indications. But if the risk of bleeding is prevailing, then dual therapy (clopidogrel plus OAC) may be preferred for 12 months (14). The uncertainty about this issue before the DAPT guidelines, and the lack of a clear proposal, could partly explain the difference in participants' responses.

The AFTER (Atrial Fibrillation in Turkey: Epidemiologic Registry) study, which was conducted with 2242 AF patients in Turkey, stated that the most important reason for patients not taking OAC (69\%) is the physician negligence (19). According to another study, the most frequent reason for not giving OAC treatment was the low tendency of physicians to prescribe the drug (74.3\%)(20). Effective INR levels were achieved in $52.4 \%$ of the patients using VKA due to AF (21). Considering all these data, it can be said that more time and attention should be given to AF patients, and the management of these patients should be improved.

The reason for these different approaches by experienced invasive cardiologists may be partially due to inadequate follow-up to the current guidelines, the lack of standardization in different invasive centers, the nonspecificity of invasive centers interested in arrhythmias and AF in particular, or ignoring $\mathrm{AF}$ as an important cause of morbidity and mortality.

\section{CONCLUSION}

This survey evaluated the definition of AF, the preferences for rate or rhythm control, the approach to using anticoagulants in different situations, the role of invasive treatment in $\mathrm{AF}$, and the approach to the association of AF with coronary artery disease. We have demonstrated that invasive cardiologists may have heterogeneous behaviors and tendencies in the diagnosis, treatment, and follow-up of AF.

Acknowledgment: None declared.

Conflict of interest: Authors of this study do not have any conflict of interest.Conflict of interest: Authors of this study do not have any conflict of interest.

\section{REFERENCES}

1. Bjorck S, Palaszewski B, Friberg L, Bergfeldt L. Atrial fibrillation, stroke risk, and warfarin therapy revisited: a population-based study. Stroke. 2013;44(11):3103-8.

2. Haim M, Hoshen M, Reges O, Rabi Y, Balicer R, Leibowitz M. Prospective national study of the prevalence, incidence, management and outcome of a large contemporary cohort of patients with incident non-valvular atrial fibrillation. J Am Heart Assoc. 2015;4(1):e001486.

3. Uyarel H, Onat A, Yüksel H, Can G, Ordu S, Dursunoğlu D. Incidence, prevalence, and mortality estimates for chronic atrial fibrillation in Turkish adults. Turk Kardiyoloji Dernegi arsivi: Turk Kardiyoloji Derneginin yayin organidir. 2008;36(4):214-22.

4. Pisters R, Lane DA, Nieuwlaat R, de Vos CB, Crijns HJ, Lip GY. A novel user-friendly score (HAS-BLED) to assess 1-year risk of major bleeding in patients with atrial fibrillation: the Euro Heart Survey. Chest. 2010;138(5):1093-100.

5. Lip GY, Nieuwlaat R, Pisters R, Lane DA, Crijns HJ. Refining clinical risk stratification for predicting stroke and thromboembolism in atrial fibrillation using a novel risk factor-based approach: the euro heart survey on atrial fibrillation. Chest. 2010;137(2):263-72.

6. Kirchhof P, Benussi S, Kotecha D, Ahlsson A, Atar D, Casadei B, et al. 2016 ESC Guidelines for the management of atrial fibrillation developed in collaboration with EACTS. Eur Heart J. 2016;37(38):2893-962.

7. Halperin JL, Hart RG. Atrial fibrillation and stroke: new ideas, persisting dilemmas. Stroke. 1988;19(8):937-41.

8. Calkins H, Hindricks G, Cappato R, Kim YH, Saad EB, Aguinaga L, et al. 2017 HRS/EHRA/ECAS/APHRS/SOLAECE expert consensus statement on catheter and surgical ablation of atrial fibrillation. Heart Rhythm. 2017;14(10):e275-e444.

9. January CT, Wann LS, Alpert JS, Calkins H, Cigarroa JE, Cleveland JC, Jr., et al. 2014 AHA/ACC/HRS guideline for the management of 
patients with atrial fibrillation: a report of the American College of Cardiology/American Heart Association Task Force on Practice Guidelines and the Heart Rhythm Society. J Am Coll Cardiol. 2014;64(21):e1-76.

10. Mohanty S, Santangeli P, Mohanty P, Di Biase L, Holcomb S, Trivedi C, et al. Catheter ablation of asymptomatic longstanding persistent atrial fibrillation: impact on quality of life, exercise performance, arrhythmia perception, and arrhythmia-free survival. J Cardiovasc Electrophysiol. 2014;25(10):1057-64.

11. Valgimigli M, Patialiakas A, Thury A, McFadden E, Colangelo S, Campo $G$, et al. Zotarolimus-eluting versus bare-metal stents in uncertain drug-eluting stent candidates. J Am Coll Cardiol. 2015;65(8):805-15.

12. Ariotti S, Adamo M, Costa F, Patialiakas A, Briguori C, Thury A, et al. Is Bare-Metal Stent Implantation Still Justifiable in High Bleeding Risk Patients Undergoing Percutaneous Coronary Intervention?: A Pre-Specified Analysis From the ZEUS Trial. JACC Cardiovasc Interv. 2016;9(5):426-36.

13. Authors/Task Force m, Windecker S, Kolh P, Alfonso F, Collet JP, Cremer J, et al. 2014 ESC/EACTS Guidelines on myocardial revascularization: The Task Force on Myocardial Revascularization of the European Society of Cardiology (ESC) and the European Association for Cardio-Thoracic Surgery (EACTS)Developed with the special contribution of the European Association of Percutaneous Cardiovascular Interventions (EAPCI). Eur Heart J. 2014;35(37):2541-619.

14. Valgimigli M, Bueno H, Byrne RA, Collet JP, Costa F, Jeppsson A, et al. 2017 ESC focused update on dual antiplatelet therapy in coronary artery disease developed in collaboration with EACTS: The Task Force for dual antiplatelet therapy in coronary artery disease of the European Society of Cardiology (ESC) and of the European Association for Cardio-Thoracic Surgery (EACTS). Eur Heart J. 2018;39(3):213-60.

15. Connolly SJ, Ezekowitz MD, Yusuf S, Eikelboom J, Oldgren J, Parekh A, et al. Dabigatran versus warfarin in patients with atrial fibrillation. $\mathrm{N}$ Engl J Med. 2009;361(12):1139-51.

16. Patel MR, Mahaffey KW, Garg J, Pan G, Singer DE, Hacke W, et al. Rivaroxaban versus warfarin in nonvalvular atrial fibrillation. N Engl J Med. 2011;365(10):883-91.

17. Granger CB, Alexander JH, McMurray JJ, Lopes RD, Hylek EM, Hanna M, et al. Apixaban versus warfarin in patients with atrial fibrillation. $\mathrm{N}$ Engl J Med. 2011;365(11):981-92.

18. Giugliano RP, Ruff CT, Braunwald E, Murphy SA, Wiviott SD, Halperin JL, et al. Edoxaban versus warfarin in patients with atrial fibrillation. N Engl J Med. 2013;369(22):2093-104.

19. Ertas F, Kaya H, Kaya Z, Bulur S, Kose N, Gul M, et al. Epidemiology of atrial fibrillation in Turkey: preliminary results of the multicenter AFTER study. Turk Kardiyol Dern Ars. 2013;41(2):99-104.

20. Ertas F, Duygu H, Acet H, Eren NK, Nazli C, Ergene AO. [Oral anticoagulant use in patients with atrial fibrillation]. Turk Kardiyol Dern Ars. 2009;37(3):161-7.

21. Alışır Mf, Keçebaş M, Beşli F, Çalışkan S, Güngören F, Yıldırım A, et al. Varfarin kullanan hastalarda etkin INR düzeyi oranları ve etiyoloji ile olan ilişkisi. Turkiye Klinikleri Journal of Medical Sciences. 2013;33(3):868-73. 